\title{
SEMANTICS OF SOME ARABICISMS EXPRESSING THE SUBJECT OF EDUCATION
}

\author{
Nargiza Rashidova \\ Senior Teacher of "Oriental languages", Department in Uzbek language and Literature, University \\ named after Alisher Navoiy
}

Article DOI: https://doi.org/10.36713/epra4163

\begin{abstract}
The article studies some of the Arabic borrowings which are in use in Uzbek. Arabic borrowings are used in various fields. In particular, they are also there in the field of education. Some of the lexemes that are used in the field of education have been studied. Their lexical meanings have been studied, and their semantics have been carefully paid attention. In the study of the semantics of lexemes, the existence of semantics is explained in detail on the basis of a table.
\end{abstract}

KEY WORDS: education, semantics, lexeme, Arabic borrowings, domla, muallim, borrowing, analysis, field, layer.

\section{DISCUSSION}

The lexical fund of Uzbek language includes original and borrowed word layers. The layer of borrowings was enriched through words taken from Persian-Tajik and Arabic up until the beginning of $\mathrm{XX}$ century. By the beginning of the XX century, some of the Russian words were borrowed into Uzbek, and later some other international words entered Uzbek though Russian. Although the process of borrowing Persian-Tajik and Arabic words became lose for a while, the words borrowed from them stayed as a staple layer vocabulary fund of Uzbek. The Persian-Tajik and Arabic words claimed their layer status more than Russian words. It is difficult to distinguish them from other words before analysis of etymology and dictionaries. These borrowed words are considered to be borrowed only for the scholars, and for the public they have become an integral original layer words. Semantic development processes of borrowed words have taken place in accordance with Uzbek. In other words, the semantic of Arabic words have undergone changes in the process of historical development. These words began to mean a complete another semantical meaning than they actually meant in Arabic. The case is unique to use of such borrowing in Uzbek and it is justified by the rule that lexemes have to adjust into internal linguistic development of a certain language. For instance, the change in the meaning of word mehnat from "tortures and agonies" into "an activity with a fruitful result or the change of the meaning of the word maraz from "illness" into "ill behavior or an ill-behaved person" are clear example of how the words change their semantically and how they got absorbed into Uzbek.

In Uzbek, there is a word arabi, which was introduced into Uzbek by the impact of Arab culture, which is used towards things and animals to mean that they originated from Arabia. Some examples of usage of the word is arabi gilam (a carpet from Arabia), arabi ot (a horse from Arabia), but a word or 


\section{EPRA International Journal of Research and Development (IJRD)

a phrase borrowed from Arabic language is referred to as Arabicism in the science of linguistics ${ }^{1}$.

Arabicism has been widely used in all spheres of socio-cultural life of Uzbek people to express various phenomena. It has been in wide use for social sphere of life. One of the social spheres to use Arabicism actively is the field of education.

The introduction of Arabicism into education process is connected with the following factors:

1. As a result of the Arab conquest, features unique to Arab education directorship was brought into Uzbek education system. Consequently, lexical units to express terms which are peculiar to Arab education directorship got borrowed into Uzbek.

2. Arabicism was introduced as a result of studying examples of Arab culture and through sources in Arabic language.

Arabicism in Uzbek has undergone a long period of historical stages from the time they were first borrowed to their current usage. In these historical periods, lexical-semantic processes in Uzbek lexical fund are there to reveal semantic development of Arabicism.

We observe changes in the semantics of Arabicisms based on the analysis of some lexemes that are actively used in the education system, expressing the subject of education.

One of the lexemes to denote "a person who educates" who is a subject of education is expressed through the word domla. In “O'zbek tilining izohli lug'ati" (Monolingual dictionary of Uzbek) the lexeme domla and its form domullo which has been phonetically changed were particularly paid attention:
Домла cm. 1 Домулла. [ф.+хинд. دادا ота, катта +a. Уे -ўқитувчи; рухоний олим ${ }^{2}$. Ўзбек тили изохли луғатида «домулла» лексемасининг маъноси - 1) мадраса ўқитувчиси; 2) диний урф одатларининг ижрочиси; 3) замонавий олий мактаб ўқитувчиси; 4) устоз, илмий рахбар³.

Domla st. 1. Domulla [Persian +Indian دادا father, great+ Arabic $\bar{\gamma}_{\mathrm{s}}$ - teacher; cleric]. The meaning of the lexeme «domullo» in monolingual dictionary of Uzbek - 1) teacher at madrasah; 2) the performer of religious rituals; 3 ) teacher of modern higher school; 4) master, scientific advisor.

The word was defined as a hybrid unit formed by Persian +Indian and Arabic. The lexeme formed in Arabic and borrowed into Uzbek from Arabic.

On the basis of the definitions provided in the dictionary, we observe the lexeme domla has the following meanings:

\footnotetext{
${ }^{1}$ Ўзбек тилининг изохли луғати.І.-Тошкент, 2006.-P.93
}

\footnotetext{
2 Ўзбек тилининг изохли луғати.І.-Тошкент, 2006.-Б.642

${ }^{3}$ Ўзбек тили изохли луғати, 1 том, Т.2006., Б.642.
} 


\section{EPRA International Journal of Research and Development (IJRD)}

Volume: 5 | Issue: 9 | September 2020

- Peer Reviewed Journal

\begin{tabular}{|c|c|c|c|c|c|}
\hline \multirow[b]{2}{*}{$\begin{array}{l}\text { Meanings of the lexeme domla given } \\
\text { in the monolingual dictionary }\end{array}$} & \multicolumn{5}{|c|}{ Meanings of the lexeme domla } \\
\hline & $\begin{array}{l}\text { "Religious } \\
\text { educator" }\end{array}$ & $\begin{array}{c}\text { "An } \\
\text { educated } \\
\text { person" }\end{array}$ & "Educator" & $\begin{array}{l}\text { "Sorcerer } \\
\text { who uses } \\
\text { religious } \\
\text { knowledge } \\
\text { for a magic } \\
\text { spell" }\end{array}$ & $\begin{array}{c}\text { "Someone } \\
\text { who claims } \\
\text { to be able } \\
\text { to heal } \\
\text { others" }\end{array}$ \\
\hline $\begin{array}{l}\text { "A form of respectful address to any } \\
\text { scholar" }\end{array}$ & & & + & & \\
\hline "Religious school teacher" & + & + & + & & \\
\hline $\begin{array}{l}\text { "A mullah who graduated from a } \\
\text { madrasah" }\end{array}$ & & + & & & \\
\hline "A mullah who leads the mosque" & + & + & & & \\
\hline "A person who deals with sorcery" & & & & + & + \\
\hline $\begin{array}{l}\text { "Secondary and high school teacher; } \\
\text { scientific adviser, teacher" }\end{array}$ & & + & + & & \\
\hline
\end{tabular}

The analysis of the lexeme domla has revealed that it has the following meanings: 1. "Religious educator". 2. "An educated person". 3. "Educator". 4. "Sorcerer who uses religious knowledge for a magic spell". The meaning "Educator" is the main semantic function of the word, while the others emerged later. The meanings of "an educated person" and "an educator" have always been there and they still are there in the semantic function of the word. The meaning of "Sorcerer who uses religious knowledge for a magic spell" emerged lately, and it is connected with culture of the nation, national views, customs and traditions.

All meanings of the word domla carries gender, the lexeme is used only for masculine. This roots back the time when women never served any of the functions mentioned above. Lexeme's meanings "Secondary and High School Teacher; scientific leader, master" were formed under the influence of the socio-political and cultural environment of the second half of the XX century, in which there is no gender identity. The lexeme is applied in student speech to the person teaching in a higher education institution. The lexeme is applied to both sexes in this sense. "Domulla" is the most widely used meaning of the lexeme "domla" today - in the sense of a modern high school teacher, mentor and scientific advisor. This lexeme is also widely used in its original sense, that is, in relation to a person who has religious knowledge. This word is not used in the speech of secondary school pupils. But the use of the lexeme in relation to the secondary education teacher can also be observed in the speech of the parents of the pupils, the representatives of the neighborhood.

The commentary in the glossary, "a form of respectful treatment of any scholar," needs to be clarified. According to A. Irisov, the lexeme domla is synonymous with the lexeme (domulla), and the root is considered to be the lexeme «alim». It is used for scholars, university teachers, doctors of science, and great writers ${ }^{4}$. In the semantics of a lexeme, the semantics of "teaching" and "speaking" predominate. Hence, the lexeme of domla is applied not to any educated person, but mainly to the person who teaches. The following example also proves our point: Shaykhzoda domla, although he did not teach me, taught at the institute where I studied ${ }^{5}$.

In the educational process, the word ustoz (teacher) of Persian-Tajik origin is used synonymously with the lexeme domla. This lexeme is especially active in the secondary education system. There is an expansion in the semantics of the lexeme ustoz, which is used in relation to any educator, except for the meaning of "an example", "an exemplary person". The synonyms of the lexeme domla also differ regionally. In some areas, female teachers are referred to as opoy or mullah opa, while in some areas, such as the districts of Kashkadarya region, the word o'qituvchi is generally used. The word muallim, which is synonymous with the lexeme domla, is specific to the artistic style.

Muallim [Arabic. Ses educator, teacher, mentor]. 1. A person who teaches; teacher, pedagogue. 2. Educator, a person who educates someone on something; can also be referred to as ustod or ustoz ${ }^{6}$. In certain regions, for instance, in parts of Tajikistan where Uzbeks reside the term

\footnotetext{
${ }^{4}$ ИрисовА.,Тошкентда арабшунослик.Қисқача очерк (Арабистика в Ташкенте. Краткий очерк).Т.1964,Фан

${ }^{5}$ Ўзбек тилининг изохли луғати.І.-Тошкент, 2006.-Р.642

${ }^{6}$ Ўзбек тили изохли луғати, II том, Т.2006., Б.623
} 


\section{EPRA International Journal of Research and Development (IJRD)

muallim is used for a male pedagogue and muallima for a female pedagogue.

The use of the lexeme domla is wider than that of muallim and its frequency is also much higher than that of the later.

The lexeme o'qituvchi which is considered to be partial synonymous of domla is mainly used as a noun referring to a person. It is almost never used as an addressing phrase. The lexeme domla is used both as a proper noun and as a term to address.

The following conclusion can be drawn after the analysis of the lexeme domla which serves to express education subject.

1. Arabicisms assimilated into the Uzbek language and for a long time obeyed the laws of semantic development of this language. For example, the semantic change of the lexeme domla, its use in the sense of "teacher in higher education", the absence of gender specificity is a product of subsequent semantic development.

2. As a result of the active use of Arabicisms, the Turkic words, the range of consumption of their stratified units, narrowed or disappeared from consumption. There is also the meaning of "healing" in the sense of "sorcery with the help of religious knowledge", "a sorcerer who claims to use magic spells in the name of religion". The lexeme emchi, which represents the person performing this function, has fallen out of use within the literary language. It has survived only in some areas.

3. Arabicisms assimilate into the Uzbek language and participate in lexical-semantic paradigms within this language. The lexeme domla enters into a synonymous relationship with a number of lexemes and is distinguished by its specific meanings.

Arabicisms can be considered as an active part of the Uzbek language lexical fund.

\section{BIBLIOGRAPHY}

1. Ўзбек тилинине изохли луғати.I том, $T$. 2006.

2. Ирисов А., Тошкентда арабшунослик. Қисқача очерк (Арабистика в Ташкенте. Краткий очерк).-Т.1964,Фан

3. Узбек тили изохли луғати, II том, Т.2006. 